\title{
Politics and Policies of Higher Education: Policy Transfer and the Bologna Process
}

\author{
Simona Torotcoi \\ Doctoral School of Political Science, Public Policy and International Relations \\ Central European Universit, Vigyázó Ferenc u. 2. Room 220/1051 Budapest, \\ Hungary, e-mail: Torotcoi_Simona@phd.ceu.edu
}

\begin{abstract}
In this paper, I show how a policy transfer framework can be applied to higher education in Europe, and can provide a different understanding on the relationship between multi-level governance, policy transfer and policy implementation. First, the paper offers an overview of the multi-level-ness of the European Higher Education Area (levels, actors, issues). This is paramount in a time in which discussions about governance and implementation issues are on the verge. Secondly, building on the given context, this paper applies to higher education a framework for analysing policy transfer (Dolowitz and Marsh 2000, p. 9). Thirdly, and most importantly, by combining the policy transfer and policy implementation literature, this paper puts forward a framework for analysing what facilitates or obstructs transfer in multi-level, multi-actor setting. Differentiating between three levels of implementation, namely: adoption, transposition and institutional implementation would reflect into a more appropriate approach for researching the different implementation outcomes, since the Bologna Process relies on national and institutional elements. This is significant because higher education is not an area under EU competencies; however there are similarities with other areas, e.g. the EU social policy, in terms of the method employed (OMC) to achieve the set goals, the role of the EU institutions, etc.
\end{abstract}

Keywords: higher education, multilevel governance, policy transfer, policy implementation, Bologna Process 


\section{The Bologna Process: What is it?}

There has always been an interest in exploring compliance and implementation of international treaties and laws, either from the perspective of the involved actors, the process itself and its analysis, trends in development, or of the issues the key stakeholders are dealing with. However, not until recently the topic of examining the implementation of voluntary policy agreements has started to be a topic of discussion. Enhancing policies that act in ways that are consistent with the goals and objectives intended by the policy makers in international voluntary agreements represents a starting point for the members of that agreement to express their commitment and coordinate their policies.

The Bologna Process, more recently known as the European Higher Education Area, is a voluntarily agreed, collective and intergovernmental effort to strengthen the competitiveness and attractiveness of European higher education by helping diverse higher education systems to converge towards more transparent systems and to create a harmonized European higher education area. The foundation of the Bologna Process started with Claude Allegre, the French Minister for Education, who in 1998 together with his counterparts from Germany, the UK, and Italy decided to launch a European initiative, a "Joint declaration on the harmonisation of the architecture of the European higher education system" otherwise known as the Sorbonne Declaration. According to Racke (2006), "the harmonization of higher education structures was meant to increase the employability of graduates across Europe" (p. 2). Through the Declaration, the ministers "committed themselves to encouraging a common frame of reference, aimed at improving external recognition and facilitating student mobility as well as employability" (Racke, 2006). According to Racke (2006), this cooperation was triggered by the fact that, through it, member states could address common European problems, which otherwise could not be dealt with at national level. This fact is actually reflected even in later reports, where it is stated that member states commit themselves to the process and use the Bologna Process for national purposes (Kauko, 2012). By example, Claude Allegre, based on prior reports, which were proposing the introduction of the two-cycle 
8 Journal of Research in Higher Education • Vol. I, No. 2, 2017

system; compatibility with other European systems; and promotion of international attractiveness, wanted to reform the French higher education system. Fearing of strong resistance from universities, academics and students, Allegre invited his counterparts to join introducing such reforms through a European initiative, which would be easier rather than facing the potential opposition at domestic level. This idea is supported also by Moravcsik (1994, p. 1), who claims that "international cooperation redistributes domestic power resources in favour of national executives".

In this respect, Allegre and his counterparts took the Sorbonne initiative outside the EU framework in order to avoid an involvement of the European Commission, and supported the idea that it should be based on intergovernmental cooperation and not be part of the Community policy. According to Racke (2006), the Bologna Process was initiated outside the EU as ministers wished to maintain full control over the process and sought to avoid a transfer of competences or even of standardization of European higher education systems (p. 1).

Using the distinction between supranationalism and intergovernmentalism will contribute to understanding the origins, the context and the development of the Bologna Process, but also how the agreed commitments/policies are reflected at the participating countries level. Applied to the Bologna Process, this distinction presents to what extent the EU institutions and conventions are interfering or overlapping with the overall Process and its intergovernmental nature, and whether they are influencing in one way or another its level of transposition and implementation. Both concepts, supranationalism and intergovernmentalism, refer to the relationship between three elements: the role of the participating countries, the power-relations between them, and the existence or not of a certain authority. On the one hand, intergovernmentalism focuses on the role and importance of member states (currently 49 countries acting as main actors) in the process of setting goals and policies (horizontal policy-making). Supranationalism, on the other hand, refers to the amount of power given to an authority which is higher than the state (EU institutions especially the Commission, the Council of Europe, European Council, including treaties, and other legally binding documents such as Lisbon Recognition Convention- a top-down policy-making approach). 


\section{Intergovernmentalism}

In 1998, through the Sorbonne Declaration, member states (their ministers) "committed themselves to encouraging a common frame of reference, aimed at improving external recognition and facilitating student mobility as well as employability", and therefore agreed to design policies in order to enhance student mobility, to promote the attractiveness of the member states higher education systems by facilitating recognition through a system based on two main cycles, the implementation of the ECTS scheme and of the Lisbon Recognition Convention (LRC), a system which aims to facilitate the recognition of studies including the assessment of qualifications, the recognition of qualifications giving access to higher education, and the recognition of periods of study and of higher education qualifications.

A year later, through the Bologna Declaration (1999) strong emphasis was put on more European co-operation in quality assurance and the promotion of the European dimension in higher education. In 2001, through the Prague Communiqué, member states were encouraged to create lifelong learning policies, to facilitate the partnership of higher education institutions and students in promoting the attractiveness of the European Higher Education Area (EHEA), and policies aiming at the social dimension of higher education, including the access of underrepresented groups. Later on, followed the introduction of stocktaking reports and the doctoral studies as a third cycle, and the idea of cooperating with other parts of the world (Bergen Communiqué 2005), international openness, policies focusing on student-centred learning and the teaching mission of higher education, and also multidimensional transparency tools and funding (Leuven/Louvain-la-Neuve Communiqué 2009).

Every two or three years Ministerial meeting are being organized in order to evaluate the progress made within the EHEA and to agree on further steps to be taken. Each meeting produced a communiqué based on ministers' deliberations, which indicates the progress that has been achieved but also sets new priorities through declarations. This is what I call the Bologna "policy scripts". Besides these scripts, it is worth mentioning the LRC, which is calling participating countries to recognize "higher education qualifications in the academic field within Europe". The Convention sets a number of basic requirements and 
acknowledges that individual countries could engage in "an even more constructive scheme". This EU aspect coinciding with the Bologna Process, sometimes neglected by those interested in the overall Process, represents one of the cornerstones of the Process since it constitutes the only legally binding document, a fact that might also explain the different levels of compliance compared with the other agreed commitments.

Nevertheless, Bologna cannot be reduced only to the work done by the Ministers of Education or country representatives participating in the ministerial meetings. In total there are 58 parties: 49 participating countries (EU and non-EU), the European Commission and 7 consultative bodies. The parties are organized through different structures including a Bologna Follow-Up Group (BFUG), a Board, a Secretariat, different working groups and consultative bodies.

As far as the BFUG is concerned, it is the main follow-up structure in the Bologna Process (BP). The BFUG oversees the BP between the ministerial meetings and meets twice a year; it is chaired by the country holding the Presidency of the European Union, and it is supported by the Bologna Secretariat. Among its roles, it can establish working groups which might deal with certain topics in details based on Bologna Seminars ${ }^{1}$ input.

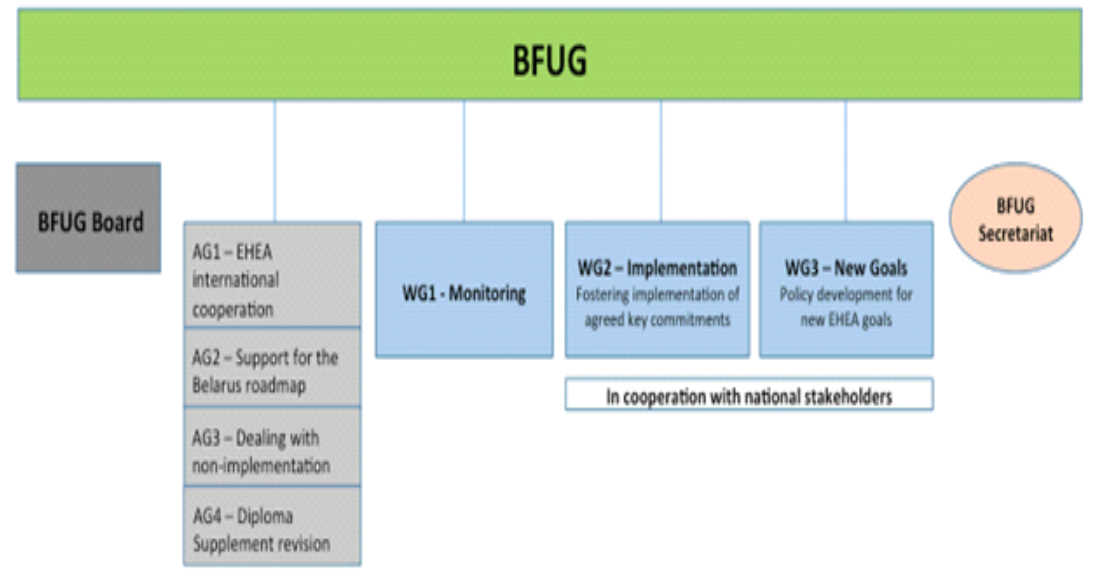

Figure 1. BFUG Organization Chart 2015-2018 (Source: EHEA, 2014)

\footnotetext{
1 Seminars are included in the Bologna Work program (elaborated after each ministerial conference and approved by the BFUG, and aim to address specific action lines) for the inter-ministerial period.
} 
The BFUG is made up of representatives of the participating countries, the European Commission, the Council of Europe, the EUA, EURASHE, ESU, UNESCO, Education International, ENQA and BUSINESSEUROPE. The BFUG is responsible of the actual work and for the development of the overall process. "It develops and decides on the rules and working methods, and sets up working groups, task forces and similar, comprising BFUG members, but on occasion also other parties, also through Bologna Conferences and seminars". Figure 1 presents the organization chart of the BFUG, including both its Working Groups (WG) and the Ad-Hoc Working Groups (AG). Beside these bodies, there are also consultative bodies such as the Council of Europe, EUA, ESU and EURASHE, but also "stakeholder organizations" which, broadly speaking, represent the higher education community.

The BFUG work is supported by the Bologna Secretariat. The Secretariat is hosted in the country which holds the next ministerial meeting. Its mandate corresponds with the period between the ministerial meetings, and its main aim is to ensure the continuity of the Bologna reforms by supporting the BFUG and its spinoff bodies ${ }^{2}$ by preparing draft agendas and reports, notes or minutes. Furthermore, the Secretariat has to provide reliable and current information and data about the progress of the educational reforms within the Bologna Process.

As far as the Board is concerned, it main aim is to prepare the BFUG meetings and therefore it usually meets every six months before the BFUG meetings, overseeing the work of the groups. It consists of the EHEA co-chairs (the EU Presidency country where the ministerial meeting took place, plus a non-EU Bologna country) and the European Commission and the consultative members (Council of Europe, European University Association - EUA, European Student Union - ESU, The European Association of Institutions in Higher Education EURASHE).

\footnotetext{
${ }^{2}$ Board, Working Groups, Networks, Ad-Hoc Working Groups, Seminars.
} 
12 • Journal of Research in Higher Education • Vol. I, No. 2, 2017

\section{Supranationalism}

The intergovernmentalist aspect does not fully capture the Bologna reality; there are also supranational aspects, most of the time neglected by scholars. This aspect implies that international organizations, more specifically EU institutions and agencies, have the power to shape and influence policy-making through their social and cognitive features (Martens et al., 2004, p. 2). As such, starting with 1993, the European Community competences expanded increasingly towards education (the Maastricht Treaty, the Amsterdam Treaty, European Council 2000 Lisbon Presidency Conclusions). As far as the "European" character of the BP is concerned, the Council of Europe plays an important role.

First, the contribution of the Council of Europe is reflected through the European Cultural Convention, (an international legal treaty created in 1954), which is one of the conditions for becoming a member in the BP. In the 1980s, the Council of Europe contributed to the model of inter-university cooperation as the privileged framework for student and staff mobility. Then, in 1997, the Council of Europe together with UNESCO adopted the Convention on the Recognition of Qualifications concerning Higher Education in the European Region (the LRC). The Convention is an international agreement, which has been ratified also by non-member states, and which aims to facilitate the recognition of studies. Starting with 1999, the Convention had to be ratified by all participating countries in the BP (Rauhvargers and Bergan, 2008).

It is worth mentioning the fact that one year after the Bologna Declaration was signed, the EU adopted the Lisbon Strategy, EU's 2000 overarching development plan. Accordingly, in the Berlin Communique (2003) it is stated that "Ministers take into due consideration the conclusions of the European Councils in Lisbon (2000) and Barcelona (2002) and calling for further action and closer co-operation in the context of the Bologna Process."

Furthermore, the Commission, through its memoranda and publications, contributes to opinion formation. Additionally, a more direct and technical form of governance, besides the regulations, refers to the use of material and financial means and incentives (Batory et al., 2011). Assessing among others the involvement of supranational institutions in European higher education, Barkholt (2005, p. 25) claims that even though higher education is not under the supervision of EU 
institutions, the European Commission does play a significant role in this sense, specifically through programmes such as Erasmus (promoting student and teacher mobility) and through the "European dimensions" of higher education (curricular development), or lifelong learning. Moreover, the choice for the open method of coordination $(\mathrm{OMC})^{3}$ to implement the BP comes exactly from the European Commission, which developed the method in order to implement the Lisbon Strategy, including the goal of making Europe "the most competitive and dynamic knowledge-based economy in the world capable of sustainable economic growth with more and better jobs and greater social cohesion".

At the Prague ministerial meeting in May 2001, it was decided to formally accept the Commission as an additional full member. Therefore, the Commission certainly is in a position to influence the direction of the $\mathrm{BP}$, its role as a partner alongside the participating countries is a normative influence to drive policy implementation. Currently, there are many joint initiatives between the BP and the EU such as the ones addressing the need to improve the existing synergies between the Bologna higher education developments and the European Research Area, or the Europe 2020 Strategy.

\begin{tabular}{|l|l|}
\hline \multicolumn{1}{|c|}{ EU Level } & \multicolumn{1}{|c|}{ BP Level } \\
\hline \multicolumn{2}{|c|}{ Characteristics } \\
\hline $\begin{array}{l}\text { Policy entrepreneurship from some national } \\
\text { capitals and the active involvement of the } \\
\begin{array}{l}\text { European Council in setting the overall } \\
\text { direction of policy }\end{array}\end{array}$ & $\begin{array}{l}\text { The role of the founding countries: France, } \\
\text { Italy, Germany, the UK. The "supervision"/ } \\
\text { "observatory" role of the Commission. The } \\
\text { countries taking over the responsibility of } \\
\text { hosting the Bologna Secretariat and the } \\
\text { forthcoming ministerial conference }\end{array}$ \\
\hline $\begin{array}{l}\text { The predominance of the Council of Ministers } \\
\text { (or an equivalent forum of national ministers) } \\
\text { in consolidating cooperation }\end{array}$ & $\begin{array}{l}\text { The Bologna Follow Up Group oversees the } \\
\text { process between the ministerial meets at least } \\
\text { once every six months and chaired by the }\end{array}$ \\
\hline
\end{tabular}

\footnotetext{
${ }^{3}$ According to the Official website of the European Union, the OMC is a framework for cooperation between the EU Member States. Under it, member states evaluate one another (peer pressure), with the Commission's role being limited to surveillance. The European Parliament and the Court of Justice play virtually no part in the OMC process. The $\mathrm{OMC}$ takes place in areas which fall within the competence of the member states. It is based principally on: jointly identifying and defining objectives to be achieved (adopted by the Council); jointly established measuring instruments (statistics, indicators, guidelines); and benchmarking.
} 


\begin{tabular}{|c|c|}
\hline & $\begin{array}{l}\text { country holding the Presidency of the } \\
\text { European Union and is supported by a } \\
\text { Bologna Secretariat }\end{array}$ \\
\hline $\begin{array}{l}\text { The limited or marginal role of the } \\
\text { Commission }\end{array}$ & $\begin{array}{l}\text { Apparently limited or marginal role of the } \\
\text { European Commission }\end{array}$ \\
\hline $\begin{array}{l}\text { The exclusion of the EP and the EC] from the } \\
\text { circle of involvement }\end{array}$ & $\begin{array}{l}\text { The exclusion of the EP and the EC] from the } \\
\text { circle of involvement }\end{array}$ \\
\hline $\begin{array}{l}\text { The involvement of a distinct circle of key } \\
\text { national policy-makers }\end{array}$ & $\begin{array}{l}\text { e.g. In Romania: Executive Agency for Higher } \\
\text { Education, Research, Development and } \\
\text { Innovation (UEFISCDI) }\end{array}$ \\
\hline $\begin{array}{l}\text { The adoption of special arrangements for } \\
\text { managing cooperation, in particular the } \\
\text { Council secretariat }\end{array}$ & $\begin{array}{l}\text { Bologna Secretariat provides first draft } \\
\text { agendas for BFUG meetings, has a role in } \\
\text { drafting official documents within the } \\
\text { European Higher Education Area and provides } \\
\text { background discussion documents, liaising } \\
\text { with relevant authors as appropriate. }\end{array}$ \\
\hline $\begin{array}{l}\text { The opaqueness of the process, to national } \\
\text { parliaments and citizens }\end{array}$ & $\begin{array}{l}\text { Resistance from some governments, from } \\
\text { universities and students alike. }\end{array}$ \\
\hline $\begin{array}{l}\text { The capacity on occasion to deliver } \\
\text { substantive joint policy }\end{array}$ & $\begin{array}{l}\text { e.g. The creation of the European Higher } \\
\text { Education Area by } 2010\end{array}$ \\
\hline \multicolumn{2}{|c|}{$\begin{array}{l}\text { Variants of IT occurring outside the EU on policy issues connected to EU policy arenas, } \\
\text { characterized by }\end{array}$} \\
\hline $\begin{array}{l}\text { The use of conventions or separate treaties } \\
\text { under international law as the primary legal } \\
\text { instruments }\end{array}$ & $\begin{array}{l}\text { Lisbon Recognition Convention } \\
\text { Lisbon Cultural Convention } \\
\text { Declarations } \\
\text { Communiques }\end{array}$ \\
\hline A membership different from that of the EU & e.g. Armenia, Russia \\
\hline $\begin{array}{l}\text { Central role being played by ministers and } \\
\text { officials }\end{array}$ & $\begin{array}{l}\text { Central role being played by ministers in } \\
\text { charge of higher education }\end{array}$ \\
\hline $\begin{array}{l}\text { Very limited access for national parliaments } \\
\text { and usually no transnational parliamentary } \\
\text { forum }\end{array}$ & $\begin{array}{l}\text { Very limited access for national parliaments } \\
\text { and usually no transnational parliamentary } \\
\text { forum }\end{array}$ \\
\hline $\begin{array}{l}\text { Limited opportunities for the involvement of } \\
\text { societal groups or stakeholders }\end{array}$ & $\begin{array}{l}\text { Limited opportunities for the involvement of } \\
\text { societal groups or stakeholders, however } \\
\text { there are some e.g. European Student Union }\end{array}$ \\
\hline
\end{tabular}

Source: Author's compilation

While acknowledging that these elements are found also in other EU (and non-EU) initiatives such as Common Foreign and Security Policy, Common Security and Defence Policy, European Monetary Union 
or EU Justice and Home Affairs, from Table 1 it can be noted that not all of the Intensive Transgovernmentalism characteristics fit to the Bologna in the same way. However, similar structures and bodies exist at the BP level but these consist manly of state actors and other social or community groups.

As a conclusion for these aspects, it can be claimed that the BP is a complex process which brings together different modes of governance, of actors and institutions, a fact which can explain, for instance, why certain countries implement certain commitments, whereas other do not. However, the question of why some countries are predisposed to respond to soft law and voluntary agreements such as the BP case is still, largely, unanswered

\section{Policy Transfer and the Bologna Process}

Given the specific components of the Bologna Process, such as its character of acting as a policy model (through the joint decision-making between the Ministers of Higher Education from the member states, including the regularly occurring steps in the policymaking process), of using the open method of coordination (including the definition of common objectives to guide national policy, translating guidelines into national action plans and evaluating and benchmarking of national performance), and also its intergovernmental aspect, the Bologna Process can be identified to guide further investigation from the perspective of policy transfer.

\section{Policy/Model}

Adoption

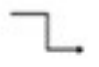

\section{Transposition}

Implementation

$\neg$ outcome/

Convergence

Figure 2. Bologna Process policy design 
Figure 2 shows the ideal policy design of the BP, namely a policy model (conveyed through the common commitments) which is used for the development of national policies; this begins by adopting the necessary legislation which provides a legal framework for addressing the policy issue at hand. Once the necessary framework is adopted at national level, the next step for the competent authorities is to translate these policy provisions into operating guidelines, action plan strategies, etc. The implementation phase refers to the stage in which these policies are put into effect at the level of higher education institutions. In other words, it refers to the practical implementation European integration scholars talk about when referring to the establishment of the necessary agencies, of the tools and instruments, of the monitoring and compliance mechanisms at the lowest institutional level (Versluis 2007, p. 53). The adoption, transposition and practical implementation stage involves solely the country at hand and its capacity to put in practice what is desired. Last but not least, as stated in the BP goals, ideally these policies will lead to convergence across participating countries, that is the process of becoming more similar (Kerr, 1983), a coming together of two or more distinct entities or phenomena. This final stage refers mainly to the final outcome of all participating countries, and their summing up of their achievements.

Before reflecting on how this policy model is working in practice, in the next sections of this paper I will be using the conceptual framework put forward by Dolowitz and Marsh (2000, p. 9) who look at the policy transfer process through a framework which is organized around several questions:

1. Why do actors engage in policy transfer? And why is the Bologna Process transferred?

2. Who are the key actors involved in the policy transfer process?

3. What is transferred?

4. From where are lessons drawn?

5. What are the different degrees of transfer?

6. What restricts or facilitates the policy transfer process?

7. How is the process of policy transfer related to policy "success" or policy "failure"? 


\section{What is the Nature of the Bologna Process Policy Transfer? Why Do Actors Engage in Policy Transfer? And why is the Bologna Process Transferred?}

According to the literature, countries engage in policy movement processes for several reasons. Maggeti and Gilardi (2015) provide several reasons for policy diffusion (emphasis added): the successes or failures of previous experiences, that policy is highly valued by peers, provides legitimacy to adopters or is widely accepted as an appropriate solution to a given problem, and the need to maintain or improve one's attractiveness with respect to its competitors (p. 1-2).

As far as the Bologna Process is concerned, it is transferred for several reasons. First, through signing the membership, the member states agree to transfer it. The Sorbonne Declaration is a document through which the founding members committed themselves to achieve the agreed goals - among which student mobility, international recognition and attractiveness, employability - reflecting their political will for a mutual benefit, and for Europe. Moreover, the fact that it invited other countries to join the initiative, made it open, emphasized the political aspect of the Process and the long-term goal of "consolidating Europe's standing in the world".

Another reason is the existence of the supranational institutions and treaties which actually push member states to implement certain policies, including the conditions for being a BP member (e.g. countries should be signatories of the European Cultural Convention and the Lisbon Recognition Convention).

Then, through the communiqués and declarations produced by the Ministers, member states and the involved actors are encouraged to promote the idea of specific measures in order to

"facilitate the proper and full implementation of the agreed Bologna principles and action lines across the European Higher Education Area, especially at the national and institutional levels, among others by developing additional working methods, such as peer learning, study visits and other information sharing activities" (Budapest-Vienna Declaration, 2010).

To learn from each other "we call upon all actors involved to facilitate an inspiring working and learning environment and to foster student-centred learning" (Budapest-Vienna Declaration, 2010) or to 
"to disseminate examples of best practice and to design scenarios for mutual acceptance of evaluation and accreditation/certification mechanisms" (Prague Communiqué, 2001).

Through cooperation in higher education, countries can strengthen their higher education system, and address common problems which otherwise could not be dealt with at the national level or by themselves. For policy-makers, introducing reforms through a common initiative would be easier than facing the potential opposition at domestic level, as cooperation can overcome resistance from universities, academics and students alike. Besides, it is a driving force in moving forward common reform agendas, it allows countries to engage in joint actions and deliver common services, and enjoy the potential benefits of cooperation. Broadly speaking, cooperation in higher education can contribute to fostering greater regional integration, competitiveness and economic growth.

\section{What is Transferred? From Where Are Lessons Drawn?}

According to Dolowitz and Marsh (1996) what is transferred are policy goals and instruments, administrative techniques, institutions, ideas, attitudes, concepts but also negative lessons. Analysing this aspect in the Bologna Process case requires looking at different aspects.

As mentioned above, through the ministerial meetings, participating countries agreed upon several commitments / policies or action lines which member states have to adopt and implement. However, while there is a lot of talk about the implementation of the Bologna Process and the consolidation of the EHEA, there is no comprehensive inventory of the Bologna policies (Zgaga, 2012). Moreover, from a conceptual point of view, it is not clear about the implementation of what we talk when assessing the level of implementation within the Bologna Process.

A simple look at the Bologna Declarations and Communiqués reveals that implementation is used when referring to reforms, goals, objectives, principles, recommendations, conventions, European standards, priorities, guidelines, strategies, tools, action lines, commitments, but also more concrete elements such as the Diploma Supplement, ECTS, mobility or quality assurance. 
What is special about the Bologna Process is the fact that reaching the common objectives (that is harmonisation of the European higher education system), through the above-mentioned action lines, entails that in some cases, at the policy level there is no conceptualisation of what is referred to by certain policies, how it should be designed or implemented, and therefore, it is left at the attitude of each member state to decide how and in which way to meet these goals. Nevertheless, some other action lines are more concrete and specific (e.g. the introduction of Diploma Supplement or ECTS) and therefore it might be clearer what and how things should be done. However, based on these broad action lines and on the guidelines provided by the Bologna follow-up groups ${ }^{4}$, most of the member states submitted national action plans (Rauhvargers \& Bergan, 2008), which represent either a mixed collection of best practices from elsewhere, with national priorities, or a repackaging or adaptation of existing policies.

According to the 2016 EHEA website: "various instruments have been developed, adopted and implemented at the European, national, regional and institutional level aiming at facilitating fair recognition of foreign qualifications and/or study periods abroad. Those instruments are amongst others, the ENIC and NARIC networks, the European Credit Transfer and Accumulation System (ECTS), the Diploma Supplement (DS), the overarching and national qualifications frameworks (QFs), the European Standards and Guidelines for Quality Assurance of Higher Education (ESG), etc."

Currently, the literature on policy instrumentation has been on the rise, mainly due to the new forms of governance and policy implementation outcomes. There is a generally agreed statement that policy instruments are techniques or tools available to governments for implementing the desired policy objectives. The roots of these policy instruments can be found merely in the policy design literature, where

\footnotetext{
${ }^{4}$ According to the official Bologna Process website July 2007 - June 2010, the BFUG is composed of representatives of the member states, European Commission, Council of Europe, UNESCO's European Centre for Higher Education, European University Association, European Association of Institutions in Higher Education, European Students' Union, the European Association for Quality Assurance in Higher Education, Education International Pan-European Structure, and BUSINESSEUROPE. The BFUG oversees the process between the ministerial meets at least once every six months and chaired by the country holding the Presidency of the European Union and is supported by a Bologna Secretariat.
} 
it is argued that the choices for certain policy instruments affect the later implementation stages (Sidney 2006, Schneider and Ingram 1990). Lascoumes and Le Gales (2007) define a policy instrument as:

"a device that is both technical and social, that organizes specific social relations between the state and those it is addressed to, according to the representations and meanings it carries. It is a particular type of institution, a technical device with the generic purpose of carrying a concrete concept of the politics/society relationship and sustained by a concept of regulation" (p. 5).

More precisely, they perceive an instrument as "a type of social institution (census taking, map making, statutory regulation, taxation)" which is highly related with a technique or tool. A technique is a "concrete device that operationalizes the instrument" whereas a tool is "a micro device within a technique" (Lascoumes and Le Gales, 2007, p. 5). Accordingly, they claim that a policy instrument reveals the type of relationship between the governing and the governed, and it produces a specific effect which structures public policy.

These behavioural assumptions of the policy tools are the main concern for Schneider and Ingram (1990), who provide a typology of tools and how these can help in fostering behaviour. In the following section, I will use Schneider and Ingram's (1990) typology and reflect upon the existing Bologna policy tools and instruments.

The first type of policy tools are the authority tools. These are defined as "statements backed by the legitimate authority of government that grant permission, prohibit, or require action under designated circumstances" (p. 514). In the case of BP, these types of tools refer mainly to the Bologna declarations, communiqués but also policy statements, which are the result of the ministerial meetings or policy forums. As an immediate step after the ministerial meeting, these types of documents represent political stances taken by high representatives. Generally speaking, there is a commonly agreed statement that those policy decisions are legitimate and likely to be implemented if top representatives agreed on those decisions, and have the relevant authority to claim further action. This category also includes the conventions (e.g. Lisbon Recognition Convention), strategies (e.g. Strategy for the EHEA in a global setting), guidelines (e.g. the European Standards and Guidelines for Quality Assurance of Higher Education), institutions (e.g. European Association for Quality 
Assurance in Higher Education), but also other tools such as ECTS or the Diploma Supplement.

A second category are the incentives tools, which assume "that individuals are utility maximizers and will not be positively motivated to take policy-relevant action unless they are influenced, encouraged, or coerced by manipulation of money, liberty, life, or other tangible payoff" (p. 515). While coercion is not an option in the field of higher education in Europe, since it is an area which falls under the national governments competencies, there are financial tools which target mainly mobility schemes, joint programs and other Bologna areas which overlap with the European Commission's agenda in the higher education field.

Capacity tools represent a third category in Schneider and Ingram's (1990) category. Such tools:

"provide information, training, education, and resources to enable individuals, groups, or agencies to make decisions or carry out activities. These approaches assume incentives are not an issue, but there may be barriers stemming from lack of information, skills, or other resources needed to make decisions or take actions that will contribute to policy goals" (p. 517).

Within the Bologna Process, these capacity tools are reflected through several elements. First, there are trainings on different aspects of the BP, which bring together the responsible actors for the implementation of those elements. Such an example is the training on "Higher Education Reform in Europe: The Bologna Process" organized by the National Academic Recognition Information Centres, on the recognition of higher education qualifications. Another manifestation is through the development of data collection mechanisms (Leuven/ Louvain-la Neuve Communiqué 2009) which allow countries and institutions to compare themselves across different aspects in order to know what is going on in different settings (e.g. Bologna with Student Eyes). In a similar fashion, the aim of highly desired multidimensional transparency tools (such as rankings) is "to enable understanding of the diversity of higher education provision, nationally and cross-nationally, in order to support users in making informed decisions" (Vercruysse and Preoteasa, 2012, p. 13). 


\section{What Are the Different Types and Degrees of Transfer? How is the Bologna Process Transferred?}

The literature identifies two main types of policy transfer. The first one refers to voluntary transfer, where countries which are dissatisfied with their current policies seek to transfer more effective and efficient policies from other countries, or they are also learning and getting inspired from other countries and therefore adjusting their existing policy. The second type of transfer is the coercive one, which can be direct and indirect. The former refers mainly to the situation when an institution is forcing a policy on another institution or country, in most of the cases the existence of a supranational institution and sanctions is essential for the transfer. The latter refers to a certain degree of international or supra-institutional influence, and that country's understanding of being mutually dependent on the others and therefore, the fear of being left behind. In the case of BP, at the country level there is a clear voluntary aspect of the BP; however, once there is a law or a regulation in place which targets higher education institutions or agencies, the transfer becomes mandatory.

According to Rose (1995), these types of transfers are strongly connected with different degrees of transfer. The first type is copying, where a policy is transferred and more or less it stays intact. Adaptation refers mainly to the extent to which that policy once moved is adjusting, based on the contextual differences. Hybridisation is actually combining distinguishable elements from more different policies whereas synthesis is actually combining different elements into a complete new, distinctive policy. Last but not least, inspiration is often uncritical, is a new approach which goes beyond a particular transfer. This type of discussion has also lead to contradictory evaluations of the BP in terms of success or failure. Such discussions have been driven by the proximate causes of the observed success or failure of such policies. In an attempt to provide a more nuanced understanding of policy success and failure, McConnell (2015; 2010) discards the binary distinction between success and failure and constructs a continuum on which multiple policy outcomes can be situated. As such, he argues that since policies are having different "realms" (process, programs and politics), they may fail or succeed in each of these "and along a spectrum of success, resilient success, conflicted success, precarious success and 
failure" (McConnell 2010, p. 345). Accordingly, the idea he puts forward is that one should look at the different dimensions of a policy/set of policies and examine how success and failure manifest within those dimensions.

These aspects can be also visible at the empirical level. As mentioned before, recent Bologna implementation reports (2012; 2015) have shown that there is no visible geographical pattern in terms of Bologna implementation, rather participating countries react differently to the commonly agreed policies. As such, some governments have taken serious steps in ensuring that the two-cycle system (bachelor-masters) is a reality (around 90\% of the participating countries) other governments show grey areas when it comes to recognizing prior learning credits (e.g. France, Britain), whereas others completely fail to provide completely free education for tertiary level students (e.g. Turkey). In terms of processes, studies have shown that for example, in the field of quality assurance, monitoring and enforcement agencies contribute to shaping the outcome of the intended policies.

\section{What Restricts or Facilitates the Policy Transfer Process?}

According to the literature (Rose, 1995), transfer is more likely to happen when there are fewer elements of uniqueness in that policy and also whether policy-makers preferences and values are in line with that policy, when the institutions to deliver that policy are more similar, when both countries, the importing and exporting, present similar resources to implement that policy. Moreover, it also depends on the simplicity of the cause-effect structure of that specific policy and on its potential scale of change (measured as outcome produced).

Besides these, Dolowitz and Marsh (1996), add few other reasons such as whether the policy is clear, concise and has a single goal, it depends also whether the problem the importing country is a largescale one and its complexity, whether there is a direct relationship between the problem and the policy solution to be adopted. It also depends on the degree of the perceived side effects of the policy, on the level of information agents have about how that specific policy operates in the exporting country, the easiness of identifying the predicted 
outcomes, and the existence of a certain level of persuasion (interest groups, agencies, NGOs, etc.). Following this perspective, Cairney (2011, p. 35) provides a fairly comprehensive list of explanatory factors for policy success: (1) the policy's objectives should be clear, consistent, well communicated and understood by the policy protagonists and targets; (2) when implemented, the policy should solve the problem it was intended to tackle; (3) resources should be allocated to the program as planned; (4) choosing skilful and obedient bureaucrats helps to reduce their discretion and thus, leads to a policy that is implemented as intended; (5) dependencies in the relationships between different actors and/or agencies in charge of implementation should be reduced so as to encourage cooperation; (6) support from policy makers and interest groups should be maintained throughout the policy cycle so as to ensure both its development and its continuity; and finally (7) exogenous factors such as wars and crises should be taken into account because they could undermine the policy process.

Based on a literature review on the Bologna Process and on the existing implementation theories, Table 2 presents the parties responsible for different policy making stages implementation and the relevant factors corresponding to these stages: 


\begin{tabular}{|c|c|c|c|}
\hline Bologna Process & $\begin{array}{l}\text { Implementation } \\
\text { stages }\end{array}$ & $\begin{array}{l}\text { Responsible } \\
\text { parties }\end{array}$ & Factors \\
\hline $\begin{array}{l}\text { Supranational } \\
\text { level }\end{array}$ & Decision-making & $\begin{array}{l}\text { Bologna } \\
\text { structures }\end{array}$ & $\begin{array}{l}\text { Sociopolitical conditions, } \\
\text { Consensus, policy clarity } \\
\text { and interdependence, } \\
\text { norm internalization, } \\
\text { mode of governance, EU } \\
\text { institutions, funding, } \\
\text { monitoring and } \\
\text { enforcement) }\end{array}$ \\
\hline \multirow{3}{*}{ Country level } & Adoption & Central level & $\begin{array}{l}\text { Legislation- Parliament } \\
\text { Ministerial orders, } \\
\text { Governmental decisions, } \\
\text { supranational pressure, } \\
\text { sociopolitical conditions, } \\
\text { coordination and } \\
\text { communication) }\end{array}$ \\
\hline & Transposition & $\begin{array}{l}\text { Administrative } \\
\text { level }\end{array}$ & $\begin{array}{l}\text { (Ministry, HE institutions, } \\
\text { agencies and bodies, } \\
\text { experts and professionals, } \\
\text { interest groups, policy } \\
\text { legitimacy/fit, national } \\
\text { priorities and interests, } \\
\text { cooperation, policy } \\
\text { instruments) }\end{array}$ \\
\hline & Implementation & Institutional level & $\begin{array}{l}\text { (HE institutions } \\
\text { discretion, faculty, } \\
\text { academics, staff support, } \\
\text { funding, demand for } \\
\text { change) }\end{array}$ \\
\hline System wide & $\begin{array}{l}\text { Outcome / } \\
\text { Convergence }\end{array}$ & $\begin{array}{l}\text { Participating } \\
\text { countries }\end{array}$ & $\begin{array}{l}\text { Adoption, Transposition, } \\
\text { Implementation }\end{array}$ \\
\hline
\end{tabular}

Table 2. Factors affecting the implementation stages

Reaching the common objective of convergence, harmonisation, compatibility, comparability and the creation of a common European higher education area requires to explore what are the driving forces which stand between what is intended (policy model) and what is expected (outcome/convergence). The focus on the adoption, transposition and practical implementation stages has been triggered 
by the fact that these stages represent, as presented in Table 2, different levels of implementation. For example, a country can have in place the required legal framework; however, there is nothing concretized in term of actual policies. Such a differentiation would allow for a better understanding of how different stages develop and the extent to which they precondition each other. Moreover, this aspect is relatively understudied, the existing scholarship lacking a theoretically grounded and methodological sounded explanation for the presented empirical puzzle. For example, the policy model aspect and Bologna developments have been the main area of concern for many scholars (Keeling, 2006; Matei, Craciun and Torotcoi forthcoming). Despite these scholarly trends, there is little literature on the national context and conditions participating countries present.

\section{Conclusion}

The Bologna Process is a complex setting, with a lot of actors involved and different aspects to be considered, such as country specificities (form of government, type of higher education system, etc.). As such, for the Bologna Process to be studied as a policy movement process requires a multilevel approach, including looking at the micro level and a detailed assessment of each stage in the implementation process. This paper aimed to describe the mode of governance within the Bologna, its actors, bodies and more specifically what it consists of in terms of policies. I have argued that in order to understand how the multilevel governance works for the BP, and how transfer takes place, one should distinguish between different stages and levels of implementation. 


\section{References}

Barkholt, Kasper. 2005. "The Bologna Process and Integration Theory: Convergence and Autonomy", Higher Education in Europe, 30 (1): 23-29.

Batory Agnes. 2016. "Defying the Commission: Creative compliance and respect for the rule of law in the EU", Public Administration, 94 (3): 685-99.

Bologna Declaration. 1999. Joint declaration of the European ministers of education (European Higher Education Area) of 19 June 1999. The official Bologna Process website July 2007 - June 2010.

Cairney, Paul. 2013. Policy concepts in 1000 words: Policy transfer and learning. [Online] https://paulcairney.wordpress.com/tag/lessondrawing/.Accessed August 5, 2017.

Dolowitz, David \& Marsh, David. 1996. "Who learns what from whom: A review of the policy transfer literature", Political Studies, 343-357.

Dolowitz, D.P. \& Marsh, D. 2000. "Learning from abroad: The role of policy transfer in contemporary policy-making", Governance, 13 (1), 5-24.

European Higher Education Area. 2012. The European Higher Education Area in 2012: Bologna Process implementation report. [Online] http://www.ehea.info/Uploads/\%281\%29/Bologna \%20Process\%20Implementation\%20Report.pdf_Accessed August 5, 2017.

Furlong, Paul. 2010. “Bologna's Deepening Empire: Higher Education Policy in Europe", in Dyson, K. and Sepos, A. (Eds). "Which Europe? The Politics of Differentiated Integration", (pp. 293-307). Palgrave Studies in European Union Politics.

Kauko, Jakko. 2012. "The power of normative coordination in the Bologna process how universities learned to stop worrying and to love quality assurance", Journal of the European Higher Education Area, (4), 23-40.

Lascoumes, Pierre, \& LeGales, Patrick. 2007. "Introduction: Understanding public policy through its instruments -from the nature of instruments to the sociology of public policy instrumentation". Governance, 20 (1), 1-21. 
28 Journal of Research in Higher Education • Vol. I, No. 2, 2017

Leuven/Louvain-la-Neuve Communiqué. 2009. The Bologna Process 2020 - The European Higher Education Area in the new decade. The official Bologna Process website July 2007- June 2010.

London Communiqué. 2007. Towards the European higher education: Responding to challenges in a globalised world, 18 May 2007. The official Bologna Process website July 2007- June 2010.

Maggetti, Martino \& Gilardi, Fabrizio. 2013. "How policies spread: A meta-analysis of diffusion mechanisms". Conference Paper, ISA Annual Convention, San Francisco, 3-6 April 2013.

Matei, Liviu, Craciun, Daniela, \& Torotcoi, Simona. 2017. "A resounding success or downright failure? Understanding policy transfer within the Bologna Process in Central and Eastern Europe", In Policy Experiments, Failures and Innovations: Beyond Accession in Central and Eastern Europe, (Eds) Batory A, Cartwright A, Stone D. Edward Elgar.

McConnell, Allan. 2010. "Policy Success, Policy Failure and Grey Areas In-Between", Journal of Public Policy, 30 (3), 345-362.

McConnell, Allan. 2015. "What Is Policy Failure? A Primer to Help Navigate the Maze", Public Policy and Administration, 30 (3-4), 221-242.

Moravcsik, Andrew. 1994. Why the European Union strengthens the state: Domestic politics and international cooperation. Harvard University: Centre for European Studies Working Paper Series, (52). Prague Communiqué. 2001. Towards the European Higher Education Area, Communiqué of the meeting of European ministers in charge of higher education, in Prague on 19 May 2001. The official Bologna Process website July 2007 - June 2010.

Racke Cornelia. 2006. "The Bologna process and the EU: Neither within nor without". Paper presented at the Third International EURREDOCS Conference. Kassel: International Centre for Higher Education.

Rauhvargers, Andrejs, Deane Cynthia \& Pauwels, Wilfried. 2009. Bologna process stocktaking report 2009. [Online] https://pdfs.semanticscholar.org/c6a5/77df2725cb41647e6caa0 26d62a9377925f8.pdf Accessed August 5, 2017.

Rose, Richard. 1991. "What is lesson drawing?" Journal of Public Policy, 11 (1), 3-30. 
Rose, Richard. 1993. Lesson-drawing in public policy: A guide to learning across time and space, Chatham House Publishers.

Schneider, Anne, \& Ingram, Helen. 1990. "Behavioral assumptions of policy tools", The Journal of Politics, 52 (2): 510-529. doi: $10.2307 / \mathrm{j} 100248$

Sin, Cristina. Veiga, Amelia \& Amaral, Alberto. 2016. European Policy Implementation and Higher Education: Analyzing the Bologna Process. Palgrave Macmillan

Sorbonne Declaration. 1998. Joint declaration on harmonisation of the architecture of the European higher education systems by the four ministers in charge for France, Germany, Italy and the United Kingdom. The official Bologna Process website July 2007- June 2010.

Veiga, Amelia. \& Amaral, Alberto. 2006. "The open method of coordination and the implementation of the Bologna Process", Tertiary Education and Management, 12 (4): 283-295.

Veiga, Amelia. \& Amaral, Alberto. 2012. "Soft law and the implementation problems of the Bologna Process", Educação, Sociedade \& Culturas, 36, 121-140.

Versluis, Esther. 2007. "Even Rules, Uneven Practices: Opening the "Black Box" of EU Law in Action", West European Politics, 30 (1): 50-67.

Wallace, H. \& Wallace, W. 2007. Overview: The European Union, Politics and Policy-Making" in Handbook of European Union Politics, eds. E.J. Knud, M.A. Pollack \& B. Rosamond, Sage, London, p. 339-358.

Zgaza, Pavel. 2005. Looking out: The Bologna Process in a global setting on the "external dimension" of the Bologna Process. [Online] http://www.ehea.info/Uploads/Documents/Bologna Process in global setting finalreport.pdf_Accessed August 5, 2017. 
